\title{
Choosing a Reverse Mortgage: Mirage, Utopia, or Atlantis
}

\author{
William Saunders, J.D. \\ Carlton Perkins, J.D., CPA \\ Texas Southern University \\ United States of America \\ Dr. Michara Delaney-Fields \\ Stephen F. Austin State University \\ United States of America
}

\begin{abstract}
Although a reverse mortgage is not the only financial product where older homeowners can tap into the equity in their homes, it is becoming a popular alternative. For years, the availability of the Home Equity Conversion Mortgage (HECM), spurred on by aggressive marketing, has been the leader in the reverse mortgage market. Thousands of assetbacked reverse mortgages have been approved which has resulted in billions of dollars of equity being transferred from homeowners to lenders. At first glance, the concept of reverse mortgages seems simple. However, the process is complicated, has a myriad of accompanying regulations and potential pitfalls. This study will examine the benefits, potential harmful effects and overall feasibility of the reverse mortgage as it applies as a financial tool for a significant segment of homeowners.
\end{abstract}

Keywords: Reverse mortgage, eligibility, equity, foreclosure.

\section{Introduction}

One of the most sought out joys of many people is when they finally pay off the mortgage on their homes. Although some people pay for their homes outright, for the overwhelming majority, a mortgage is a way of life. Extinguishing the debt is casting away the most burdensome and largest of financial obligations away forever. The security of owning one's home cannot be underestimated. Of course, with ownership, even without a mortgage, there is never a complete unfettered ownership because of the presence of certain obligations such as property taxes and homeowner's association dues. However, there is nothing so burdensome as the mortgage on the home. Once the mortgage is paid off, the homeowner has an asset and all of the equity in the home. In most cases, that homeowner is older. And correspondingly, in many cases, that homeowner has reached a point in life where retirement has occurred and earnings are less. Some have planned for this eventual event while others have not. Realizing this, the financial product of reverse mortgages was created. Once implemented, it became an opportunity where house rich, but often cash poor, individuals could tap into the equity of their homes.

A review of the nationwide statistics for reverse mortgages in 2017 shows that the mortgages are more prevalent in some areas than others. The leading states for the most reverse mortgages were California, Florida, Texas, Colorado and Arizona. Conversely, the states with the fewest reverse mortgages are Alaska, North Dakota, South Dakota, Washington, and Wyoming. The states that had the highest Principle Limit dollar amount on homes were Hawaii, California, New York, Massachusetts and Washington. West Virginia, Indiana, Oklahoma, Wyoming, and Iowa had the Lowest Principal Limit. The concept of reverse mortgages is quite simple. It is the complete opposite of a traditional mortgage. In the traditional mortgage the owner of the property borrows money to purchase a home. The lender creates a lien on the property and the homeowner pays the lender until the loan is paid off. If the note is not paid, the lender can foreclose on the property. Conversely, in a reverse mortgage, the homeowner receives payments from the lender. The lender takes a lien on the property and the payment on the loan is not due until the owner dies, sells the home or ceases to live in the home. But there are caveats. Before discussing those caveats, it should be noted that there are different types of reverse mortgages. The single purpose loan (which can be used for things such as taxes and repairs is offered by state and local governments), proprietary, and home equity conversion mortgages (HECMs). The proprietary reverse mortgages are private loans used for higher valued homes that that exceed the limits of HECMs. The HECM is by far the most popular type of reverse mortgage and is the mortgage referred to in this paper. HECMs are backed by the federal government and can be used for any purpose (FTC,2019). 
Although each type of reverse mortgage loan has guidelines and rules that must be followed, the HECM in particular has its own guidelines which must be followed and failure to do so will lead to foreclosure, and the subsequent loss of the property owner's home.

To illustrate what can happen when guidelines are not followed, Penzenstadler and Kelly (2019) state "In a stealth aftershock of the Great Depression, nearly 100,000 loans that allowed senior citizens to tap into their home equity have failed, blindsiding elderly borrowers and their families and dragging down property values in their neighborhood". In California, many senior citizens applied for and received reverse mortgages and unfortunately, according to DiPierro (2019) more than 9,000 loans failed. The data which supported the findings were based on a study by USA Today that investigated HUD information over a 29-year period and from foreclosure information from 2013-2017. Many of the reasons for the foreclosures were failures to comply with occupancy issues, and failure to pay taxes and insurance, all of which are part of the requirements outlined in the agreement to obtain a reverse mortgage.

\subsection{Present state of the reverse mortgage market}

Because of the high number of foreclosures reverse mortgages began to receive negative press and were frowned upon by many. For some, the reverse mortgage was seen as a loan of last resort. Many of the loans were considered predatory and were in some instances, directed at homeowner's located in certain neighborhoods. Senior citizens were bombarded with sales pitches from famous television and movie stars who touted the benefits of tax free cash. Advertisements, sometimes deceptive, were plentiful which declared that senior citizens could receive money from the equity in their homes to use however they wanted and they could stay in their homes risk free. An example of deception was illustrated when the Consumer Financial Protection Bureau fined three companies for using deceptive advertisements to sell reverse mortgages. Those ads were over a period of four years and resulted in a combined penalty amount of almost $\$ 800,000.00$ (Carrns,2016).

What wasn't being explained to homeowners was the high upfront costs of reverse mortgages and other costs of obtaining a reverse mortgage such as the interest rates and the eventual loss of equity. There were other pitfalls, such as spouses who were not 62 years of age or not a party to the loan. Or if the homeowner had to move or was placed in a nursing home for over the allowable time. Whether it was from a lack of contractual knowledge by the homeowners, predatory practices, or unexpected circumstances, a significant number of reverse mortgages defaulted. On one hand, this was bad for the homeowners, but on the other hand, none of these factors really affected the mortgage companies because any loss on the eventual sale of the property was covered by insurance from the Federal Housing Administration. Clearly, reverse mortgages are a win-win transaction for the lenders. The same cannot be said of the budgetary effect on the government. In 2013, the FHA needed an infusion $\$ 1.7$ billion to cover losses because of reverse mortgages. Two years later the default loans amount rose to $\$ 5$ billion, and is presently more than $\$ 13$ billion.

Recognizing that something was seriously wrong with the reverse mortgage concept and process, the FHA instituted new governmental regulations designed to protect seniors who apply for reverse mortgages. The main feature of the new guidelines was that homeowners had to meet a financial test to prove that they can comply with the costs of the reverse mortgage. Before the implementation of the new rules, the borrowers were not subject to serious income and credit checks. According to Sheedy (2019), "Borrowers will have to prove that they can handle the ongoing costs of the loan. Homeowners who don't pass the financial assessment could be denied". The lenders will look at all of the borrower's income, such as Social Security, pensions, and bank accounts. Failure to be able to meet the requirements did not automatically eliminate applicants. But, for those who did not qualify, the financial assessment required lenders to set aside a portion of the loan proceeds to ensure that taxes and insurance premiums would be met.

A recurring theme among those who faced reverse mortgages foreclosures was they were not aware of the contractual agreements. Davidoff, Gerhard \& Post (2017) stated, "Awareness of reverse mortgages is high, but knowledge of contact terms is limited". They went further to say, "We find that an important factor relating to low reverse mortgage demand is potential borrowers' insufficient knowledge, or product literacy". To ensure that homeowners fully understand the terms and ramifications of the reverse mortgage, the FHA, in their new regulations, now require applicants to complete a counseling session with an approved counselor.

Another feature of reverse mortgages, which was highly criticized, was the provisions that gave little or no protections to a non-borrowing spouse. There were cases where after the borrower died the lender foreclosed on the homes because the non-borrowing spouse was not a party to the contract. That meant that before August 4, 2014 lenders did not have to let the spouse remain in the home. To quell the uproar and address the unfairness of the regulation, new rules concerning non-borrowing spouses were implemented. It provided that a non-borrowing spouse could stay in the home after the borrower dies. However, the non-borrowing spouse cannot receive any more of the funds. In addition, the nonborrowing spouse has other eligibility requirements such as living in the house as the primary residence and also certify his or her eligibility every year or face foreclosure (Herron, 2019). 
However, there are still challenges, according to Guerin (2018), because non-borrowing spouses are not protected if the borrower moves to a nursing home or care facility for more than 12 months. This event would lead to a foreclosure on the property. She stated, at a minimum, the non-borrowing spouse should know what causes the loan to mature, what maturity events offer no protection, what must be done after the death of the borrower; and, what arrangements can be made if the borrower has to be placed in a nursing home. And it must be noted that the implemented changes only protect the non-borrowing spouse if he or she was married to the borrower at the time of the origination of the loan.

An additional regulation also addressed limitations on the amount of the loan which could be obtained through a reverse mortgage. Before addressing the amount of loan the borrower can receive, the initial principal limit (IPL) must be determined. The IPL depends on the borrowers age at the time of application, interest rate and the home's appraised value. Regulations limit to $60 \%$ the amount of the initial principal borrowers can receive in the first year of the loan (Investopedia, 2019). The funds from the loan can be distributed in one of five ways, or a combination of the choices:

1. a two year lump sum with a fixed interest rate a monthly payment with an adjustable interest ratea monthly payment for as long as the borrower stays in the home which has anadjustable rate

2. a larger term payment with an adjustable interest rate

3. a credit line which can be used at any time

The IPLwill be lower than the appraised value of the house because of the interest that will accrue on the reverse mortgage loan. In addition, the distribution will depend on other costs, particularly the interest associated with the reverse mortgage loan Herron (2019), states "Reverse mortgages are a negative amortization loan. That means the loan balance grows over time. For instance, you may borrow $\$ 100,000.00$ upfront, but by the time you pass away or sell your home and move, you will owe more than that, depending on the interest rate on the reverse mortgage".

But understanding the interest rate is not easily understood. For example, the leading HECM company is AAG. They offer the following explanation to potential borrowers: The interest rates on HECMs are comparable to other fully amortized mortgages. The interest rate a borrower pays is made up of the "index" and the "margin". The index is the market interest rate - The London Interbank Offered Rate(LIBOR) index is commonly used. The margin is set by the lender, and depends on the level of service offered to the borrower. As of November 2016, the NRMLA website calculates reverse mortgage examples using a variable 1- month LIBOR index of $.533 \%$ with an average margin of 2.5\%. for a current reverse mortgage loan interest rate of 3.033\% (known as the Initial Loan Interest Rate). Other rates and indexes are also available for example calculations. While the interest rate index can change over time for an adjustable interest rate loan, the margin cannot change and stays the same throughout the loan term (AAG, 2017).

Perhaps a person with an extremely strong understanding and knowledge of financial terms can understand this explanation. Unfortunately, many people would not only not understand the explanation, it is also doubtful that borrowers will read it.

While interest rates are a concern to borrowers because it is the main factor in the total debt owed to the lender, the homeowner will be faced with other costs. Max (2019) shows that there are origination fees which can be up to $2 \%$ of the first $\$ 200,000.00$ of the home's value or $\$ 2500.00$ plus $1 \%$ of any amount above $\$ 200,000.00$. The fee is capped at $\$ 6,000.00$. In addition, a monthly servicing fee of $\$ 35.00$, mortgage insurance of $2 \%$, and an annual $\% 0.5$ fee will be assessed. She states, "All told, for a loan of up to $\$ 200,000.00$, for instance, a borrower could pay as much as $\$ 10,000.00$ in upfront fees which are typically rolled into the loan balance plus ongoing mortgage premiums and service fees of about $\$ 1400.00$ per year".

However, when large fees are rolled over into the loan, the homeowner is truly, in effect, is adding to the cost of the loan which has no association with the appraised value of the home itself. Thus, the borrower owes more immediately, not to mention the commission that has to be paid.

The purpose of the revisions of the HUD guidelines was to bring clarity and understanding to the reverse mortgage process for future applicants. (Davidoff and Gerhard, 2017), state, "The HECM is a particularly interesting case because it is a highly complex product that embeds liquidity, longevity and home price insurance in the form of limited protection and complex refinancing options, while being geared toward poorer and older households who may be expected to have limited financial literacy. The fact that consumers are required to attend a counseling session before entering into a HECM contract indicates that the government views targeted consumers as having insufficient knowledge". Whether the goals of changes to reverse mortgage guidelines will be met remains to be seen.

\section{Future of reverse mortgage}

Seemingly, the problems of the past, and the responses to those problems, has possibly had a negative effect on the reverse mortgage market. However, the hesitancy to commit to a reverse mortgage is not new. 
Sawyer (2016) said that one reason for the hesitation was that elderly people had deeply held values relating to obtaining a debt which could affect their intergenerational obligations. Presently, the limitations on the available loan amounts and the decrease in the number of borrowers who could benefit from a reverse mortgage has been instrumental in the decrease in reverse mortgage loan applications. For example, in 2012there were 582,0000 outstanding reverse mortgages. In 2009, there were 114,692 reverse mortgage endorsements but that amount fell to 39,377 in 2017 and dropped $26.7 \%$ in 2018. According to Guerin, (2018), "HUD has said the changes are meant to ensure the programs long term viability, but dealing with persistent regulatory change has hampered lender's ability to help borrowers".

Even so, the number of reverse mortgage loan is still significant. According to the National Reverse Mortgage Lender Association (NRMLA), despite the recent decreases, the total reverse mortgage loans which have been made since inception is 1,126, 244.

However, along with this number of reverse mortgages was an associated number of foreclosures. Unfortunately, since the reverse mortgages are non-recourse loans and the lenders are paid for any shortfall, the foreclosures had a tremendous impact on the mortgage insurance fund. Specifically, HECMs were the main reason the FHA Insurance Fund, Mutual Mortgage Insurance(MMI), accrued a deficit of over \$12billion dollars. Because of this, HUD increased the premiums on reverse mortgage loans. However, despite the negative perceptions and changes in regulations, the reverse mortgage industry is seeking to adapt because the potential market is voluminous and growing every day.

At one time approximately only $2-3 \%$ of eligible Americans had a reverse mortgage. There is a great chance that percentage will increase because the pool of potential borrowers will become so much larger. The age of millions of Americans is increasing, and the equity in senior housing is over $\$ 7.14$ trillion dollars. Because Americans are living longer means seniors will have longer retirement years. For example, by 2065 the average 65 year-old female will live four years longer than she will today. Furthermore, future seniors will face rising immediate and long term healthcare costs. Some statistics show approximately $70 \%$ of those seniors will require long term care during their lifetimes (Reverse Mortgage Alert 2019).Accordingly, all of these reasons will be a part of the catalyst which will cause an increase in the potential pool of applicants for reverse mortgages.

Those seniors will require a significant of money to ensure that they can meet their financial obligations and will be able to live in reasonable comfort during their retirement years. However, many will not have funds to do so and some will need more. Ghilarducci (2019) states, "The bottom line is that Americans do not have enough retirement savings. Some may still deny there is a problem. But the number of poor or near-poor people over the age of 62 is set to increase by $25 \%$, and between 2018 and 2045 it will increase, from 17.5 million to 21.8 million".

Many of these senior citizens will be homeowners. Davidoff and Gerhard (2017) state, "Most retired homeowners own a home and home equity is a large fraction of wealth for those households. According to the 2013 Survey of Finances, $87 \%$ of U.S. households ages $65+$ own a home (the 2016 U.S. census figure is $79 \%$ ), and the value of the primary residence represents $56 \%$ of the total assets at the median". The equity in homes is a source of funds that can assist seniors during retirement, if needed. There are those who will want to use the equity in their homes to assist with retirement income, but there are others who will not want to do so.

However, research such as Boston College National Retirement Index 2010, has noted that many future retirees will not be in a position to avoid using home equity in retirement (Pfeiffer, Schaal and Salter, 2014). Thus, the dilemma that many seniors will face is will they be forced to take a HECM or other proprietary loan on their homes to meet their financial needs.

For those senior citizens who choose to avail themselves of a reverse mortgage they have to be aware that in some instances the funds received can potentially affect government sponsored programs such as Medicaid. Specifically, there is a little known provision which limits the amount of money a recipient can receive without curtailing a loss of Medicaid benefits. For a single individual that amount is $\$ 2000.00$ while couples are allowed $\$ 3000.00$. The amounts are calculated at the end of each month. During that time the liquid assets cannot exceed the threshold (the home and one car are not part of the equation and thus exempt). Exceeding the amounts could make the recipient ineligible for Medicaid.

The timing of a reverse mortgage and payment method also presents an option for senior homeowners. Many homeowners avail themselves of the lump sum method, others choose a line of credit. The decision to obtain a reverse mortgage through the line of credit feature is backed by Sacks (2017)who states, "The "almost affluent" can benefit from establishing a HECM line of credit as early as possible, particularly if they are house rich and cash poor. Taking the HECM early produces a significantly higher retirement income than a later establishment of the credit line, while reducing the probability of exhausting his or her assets". That opinion was shared by Pfeiffer, Schaal, and Salter (2014) who show that the early establishment of an HECM line of credit provides greater survival rates than those strategies where the line of credit is established after the investment portfolio is exhausted. 
With a reverse mortgage line of credit, interest does not accrue until the money is withdrawn and the line of credit grows as the same interest on the loan plus $1.25 \%$.

Unlike a withdrawal of the lump sum method of withdrawal for a reverse mortgage, which has a fixed interest rate, the line of credit has an adjustable rate feature. The line of credit is the choice of approximately $66 \%$ of the time when obtaining a reverse mortgage and the choice has increased since the HUD changes (Branson, 2019). An example of why the line of credit is so popular was given by Pfau (2019) who states

"Typically speaking the principal limit loan balance, and remaining line of credit all grow at the same rate. In rare cases in the past, a reverse mortgage included a servicing set aside that grew at a high enough expected rate that the set aside balance grew even as expenses were paid".

The options, requirements and the process show that even though the reverse mortgage concept is simple, the realities are not. There are varying opinions about whether reverse mortgages are feasible and should be avoided. Ernst (2018) warned that the closing costs, fees and interest are added to the loan balance which makes the process seem painless but the financial harm is real and devastating. He states, "For long term borrowing needs reverse mortgages are even worse. Succinctly put, in the long run a reverse mortgage results in the sale of your home at a huge discount. Ads state that a reverse mortgage allows you to use the equity in your home. Actually, a reverse mortgage will cause you to lose your equity. The cash flow that you accept, perhaps 20 percent to 50 percent of your home's value, will be all you will ever get by the time the bank effectively owns your home".

By contrast, there are those who have the opinion that reverse mortgages are indeed a wise choice for retirement planning. Bell (2018), the CEO of the Reverse Mortgage Association, is of the opinion that borrowers never give up title or ownership of their homes; and, regular payments from a reverse mortgage can help retirees stretch their retirement funds and is a valuable option even when you factor in the upfront costs. He also stated, "A 2016 study from Ohio State University that analyzed the use of reverse mortgage loans to preserve independent living showed that four out of five senior homeowners who have a reverse mortgage are satisfied with their decision to get one". The Ohio State study was conducted by Moulton, Loibl and Haurin(2016). The study had 1761 participants who had been counseled about a reverse mortgage. Some accepted the loans, others $(25 \%)$ did not, and some $(6 \%)$ terminated them. The average age of the participants was 70, and one-third were women. Nearly half of the respondents had no assets, the median amount of savings was $\$ 2,000.00$ and the average monthly income was $\$ 2,600.00$. The findings were that $83 \%$ of the respondents were satisfied with the decision to obtain a reverse mortgage.

When analyzing the demographics of that study, it is clear that the population was limited and obvious that most of the respondents took out the loans because of need. Furthermore, it would be difficult to justify such a blanket statement that $83 \%$ of reverse mortgage recipients were satisfied. Perhaps that can be said about those who participated in that particular study. However, it would be difficult to derive the same conclusion from the more than 100,000 senior homeowners whose reverse mortgages have failed. Putting the subject of satisfaction with reverse mortgages in perspective can be depend on who is being asked.

According to most surveys, the majority of current borrowers are satisfied with their reverse mortgages and have indicated that their lives are better off because of them. That the majority of current borrowers are satisfied with their reverse mortgages is not all together surprising. After all, the initial flow of funds is entirely one way. Borrowers will suddenly find themselves with substantially more money. As for borrowers 'level of satisfaction over the long-term, satisfaction is less clear because ultimately these funds need to be repaid. Reverse mortgages are always negatively amortizing, which means principal begets interest, which in turn, begets more interest. In practice, however, that means that the reverse mortgage loan balance will grow at an exponential rate. Depending on the rate of interest and the initial loan balance, the loan balance will probably approach and even exceed the value of the home after one or more decades. Perhaps a substantial portion of all borrowers might sing a different song when they receive the bill for the reverse mortgage and are confronted with the reality that the money they received was never free. At this point, the satisfaction rate is not known (Reverse Mortgage.net).

\section{Future challenges for consumers and the industry}

Because of negative perceptions, growing complaints, and lack of understanding from consumers, the FHA will continue to implement other reverse mortgages regulations. Although several reverse mortgage lenders have seen an increase in reverse mortgage endorsements, there is a continuing downward trend in the overall applications and approval. In the 2018FHA's Fiscal Year Report to Congress it showed the agency's reverse mortgage portfolio had anegative capital ratio of 19.84 percent and a negative net worth of $\$ 14.5$ billion. Thus, now the FHA is requiring lenders to provide a second independent property appraisals if it feels there are inflated property evaluations. 
This requirement is being implemented to reduce the risk to FHA's Mutual Mortgage Insurance Fund (HUD Public Affairs, 2018). Whether the reason is inflated valuations of properties, foreclosures, or the natural progression termination of the reverse mortgages loans, HUD has a significant number of due and payable reverse mortgage loans in its inventory. The number of foreclosures have caused HUD to auction off a significant number of properties. Over a period of two years HUD has sold a total of 3300residential notes that were secured with loan balances of over $\$ 660,000,000$. The mortgage loans were from single family vacant properties whose owners were deceased.

The homes were sold only to "qualified bidders" as determined by HUD. Thus, an unintended carousel effect was created. The homeowner takes a reverse mortgage, the lender advances the sum and places a lien on the house. The non-recourse loan is guaranteed by the FHA.

Subsequently, the home is foreclosed and the FHA reimburses the lender for any shortfall. HUD takes the property and auctions off the home to the "qualified buyers". This is but another example of why more regulations are inevitable for the reverse mortgage industry. Reverse mortgages have become a fixture on the financial planning platform for senior citizens. The history of the product has been fraught with successes and failures. Some homeowners have been pleased with reverse mortgages, while others have not. Unfortunately, some homeowners had to go through the foreclosure process and lost their homes. Herron (2019)states, when referencing reverse mortgages, said that reverse mortgages are a financial tool that is not good or bad and it just depends on how they are used. Reverse mortgages can serve a tool to help senior citizens with living expenses but just as there are advantages, there are certain disadvantages and risks. The biggest of which is that a homeowner could lose his/her home.

It has been an objective of the government to implement regulations to make the reverse mortgage process more transparent and to ensure that senior homeowners understand the benefits and potential drawbacks. In addition, some of the mortgage companies have revised their marketing approach. For example, AAG has changed their theme to include other products and not just concentrate on reverse mortgages. Now they offer traditional mortgages and a service to sell homes. This approach is designed to attract seniors who may not want a reverse mortgage but do want avail themselves of the cash potential in their home equity. "Retire Better", not simply reverse mortgages, is now AAG's new brand and is, according to Stringer (2019)

Designed to change the mindset around using home equity Similarly, New Retirement, is offering an online questionnaire for consumers to determine if reverse mortgages are a product that is right for consumers. They pose questions such as whether the consumer has a likelihood that they will need more money in the future, how long the consumers plan to live in their home, whether it is important to leave the home to heirs, and were they willing to use "some" equity in their homes. A score between 1-5 is assigned to each question and the total score determines whether a reverse mortgage is a good fit for the consumer. They also provide a calculator to determine the total amount of money that the consumer can obtain from his/her home.

In the final analysis, there is no one size fits all answer that will apply for those who are interested in reverse mortgages. There are examples where senior consumers will need a reverse mortgages because there is no other option. On the other hand, some will use reverse mortgages just to supplement retirement income, and others will create a line of credit reverse mortgage just in case additional funds are needed in the future. Whatever the reason, consumers must realize that reverse mortgages, despite its name, is nothing but a loan and that despite what advertisements say, the money received is not free. They also must know, despite what the new advertisements say, that the loan creates a lien on their homes. And finally, they must know that if the conditions of the loan are not met, that there is a possibility that foreclosure proceedings will be instituted. To understand reverse mortgages senior consumers should not rely solely on information from the mortgage companies. Rather, it is incumbent on them to conduct research on their own, and then obtain the services of an independent advisor.

When combined with information that is available from various governmental agencies, the mortgages and non-profit agencies, there is no reason why reverse mortgages cannot be understood. However, historically, for some, statistics show that reverse mortgages have been a mirage. It was something that they saw that just wasn't there. For them their fate was similar to the those in Plato's Atlantis whose homes and legacies disappeared. They have faced bankruptcies, evictions and foreclosures. For others, reverse mortgages have become a utopia. The product has worked for them in all the ways that was intended. In all of the scenarios, however, nothing more appropriate can be said other than Caveat Emptor, let the buyer beware.

\section{References}

American Advisors Group. (2017, December)Reverse Mortgages Rules \& Requirements. Retrieved from www.Google.com 
Bell, P. (2018, March 9). Reverse mortgages have their place. Baltimore Sun, pp.1-9.

Branson, Michael. (2019, May 30). Reverse mortgage line of credit-the credit line that grows. AllReverse Mortgages, Inc, Retrieved from https://reverse.mortgage/line-credit-of-credit.

Carrns, Ann. (2016, December 9) Reverse mortgage lenders fined for ads that tricked older borrowers. Retrieved fromwww.nytimes.com/2016/12/09/your-money/reverse-morttgage-lenders-fined-for-ads-that-tricked-olderborrowers-html.

Davidoff, T., Gerhard, P. \& Post, T.(2017). Reverse Mortgages: What homeowners(don't) know and how itmatters' Journal of Economic Behavior \& Organization, 133, 151-171. doi:https://doi.org 10.10/j.jebo.2016.11.007.

DiPierro, Amy.(2019, June 12) California seniors turned to reverse mortgages to stay in their homes. More than 9,000 loans failed.Palm Springs Desert Sun. pp. 1-9. Retrieved from, www.desertsun.com/story/money/realestate/2019/06/12/reverse-mortgage-foreclosure-seniors-california-in/and-empire-riverside-san-bernardino

Ernst, Art. (2018, March 1) Don't fall victim to the reverse mortgage con.Baltimore Sun, pp 1-9. Retrieved from www.baltimoresun.com/opinion/opinion/op-ed-03002-reverse-mortgage-20180301-story.html

Federal Housing Administration (2018). FHA to require second appraisal for certain reverse mortgages. HUD Public Affairs No.18-111, pp 1-2.

Ghilarducci, T. (2019). Americans do not have enough retirement savings, really. Forbes, 1-3 Retrieved from www.forbes.com/sites/teresaghilarducci/2019/03/28-no-americans-really-do-not-have-enough-retirementsavings/\#4a4730bd2b21.

Guerrin, J. (2018, July) Reverse mortgage volume falls to 13 year low. Housingwire, pp.1-3 Retrieved from www.housingwire.com/articles/46006-reverse-mortgages- volume-falls-

to-13-year- low.

Herron, J. (2019, June 12). Are you thinking of getting a reverse mortgage? Who should consider one and who shouldn't.USA Today, pp 1-5. Retrieved fromwww.usatoday.com/story/money /2019/06/12/reversemortgages-how-do-they-work-and-who-should-consider-one/2881617002/.

Keene, D., A. Sarnak, Coyle C. (2019). Maximizing home equity or preventing home loss: Reverse mortgage decision making and racial inequality.The Gerontologist, vol. 59 (2) pp. 242-250., doi:htpps://doi.org/10.1093/geront/gnx209.

Kopp, C.. (2015, August 16). Rules for obtaining an FHA reverse mortgage. Investopedia, pp.110. Retrieved from www.investopedia.com/mortgages/reverse-mortgage/fha-rules/McGuffin, D.( 2015) How reverse mortgages affect Medicaid and medicare. Retiring Wise, Retrieved from www.onereversemortgage.com/blog/2015/05/how-reverse-mortgages- afffect-medicai.

Moultin, S, Loibl, C., \& Haurin, D. (2017). Reverse mortgage motivations and obligations: Insight from survey data. Cityscape, 19(1), 73-98.

Neuwirth, P., Sacks B., Sacks, S. (2017) Integrating home equity and retirement savings through the rule of 30. Journal of Financial Planning, 30, (10), pp. 52-62.

NRMLA. (2017). Reverse mortgages subject of new article in journal of financial planning. Retrieved from https://www.nrmlaonline.org.

Penzenstadker N., Lowenstein J..Seniors were sold risk-free retirement with reverse mortgages, now they face foreclosure (2019, June 12)USA Today. Retrieved from https://finance.yahoo.com//news/seniors-were-soldrisk-free100319361.html

Pfau, W. (2019, January 16).Understanding why and how the HECM line of credit grows. Forbes, 2019. Retrieved fromwww.forbes.com/sites/wadepfau/2019/01/16/understanding-why-and-how-the-hecm-line-of-credit-grows /\#16ac71024738

Pfeiffer, S., Schall, A., \& Salter J., (2014) HECM reverse mortgages: Now or last resort. Journal of Financial Management, vol.2 (5), pp.44-51.

Reverse Mortgage Satisfaction Still Unknown (June, 2017) Reverse Mortgage.net.,Retrieved from www.reversemortgage.net/reverse-mortgage-stisfaction-still-unknown.

"Reverse Mortgages.(2019, May)" Federal Trade Commission, Retrieved fromwww.consumers.ftc.gov/articles/0192reverse-mortgages.

Sawyer, C..(1996) Reverse Mortgages: An innovation tool for elder law attorneys. Stetson Law Review, XXVI, pp. 617-645. 